\title{
UNIVERSITYOF
}

FORWARD

THINKING

WESTMINSTER用

WestminsterResearch

http://www.westminster.ac.uk/westminsterresearch

Hasbara 2.0: Israel's Public Diplomacy in the Digital Age

Aouragh, M.

This is an Accepted Manuscript of an article published by Taylor \& Francis in Middle East Critique, 25 (3), 271-297. The final definitive version is available online:

https://dx.doi.org/10.1080/19436149.2016.1179432

(c) 2016 Taylor \& Francis

The WestminsterResearch online digital archive at the University of Westminster aims to make the research output of the University available to a wider audience. Copyright and Moral Rights remain with the authors and/or copyright owners.

Whilst further distribution of specific materials from within this archive is forbidden, you may freely distribute the URL of WestminsterResearch: ((http://westminsterresearch.wmin.ac.uk/)).

In case of abuse or copyright appearing without permission e-mail repository@westminster.ac.uk 


\title{
Hasbara 2.0: Israel's Public Diplomacy in the Digital Age
}

\author{
MIRIYAM AOURAGH
}

\begin{abstract}
The Internet has been a counter-public space for Palestinian liberation politics for over a decade, and digital technologies have become an increasingly important tool for solidarity groups across the world. However, the Israeli state and Zionist supporters worldwide are harnessing the same technologies and platforms to mobilize technology primarily to increase pro-Israel sentiments. The aims of this article are to examine hasbara [Israeli public diplomacy] through an exploration of similar diplomacy programmes; to illustrate how social media have affected the basic algorithms of hasbara; and to probe the assertions of hasbara in the light of pro-Palestinian solidarity. Through a study of public diplomacy, this article critically analyzes hasbara as a site of contestation and a method that is hampered by contradictions. On the one hand, there has been a massive growth in hasbara in recent years-indicated by the increase in funding for it and by its professionalized and centralized character; and on the other hand, hasbara has attracted sharp critiques in Israel for its reputed failures. To understand this contradiction, hasbara must be placed within the context of Israel's settlercolonialism, which sets the state apart from other 'post-conflict' states. This article reviews the methods utilized in hasbara, as well as their readjustment in the context of recent wars. Events in 2014 illustrate that hasbara actually destabilizes Israel's diplomacy. Online journalism and the suppression of solidarity for Palestine together stimulate more criticism and, in turn, help to shift public opinion. Paradoxically, therefore, adjustments ('hasbara 2.0') have underlined the image of Israel as a colonial power engaged in violent occupation.
\end{abstract}

Key Words: BDS; Gaza; Internet; Israel; Palestinian Liberation; Propaganda; Public diplomacy; West Bank; Zionism

There have been many sterling pieces researching and undermining Israel's Gaza fairy story, but even they are evidence that Israel has succeeded in setting an agenda. ${ }^{l}$

In the summer of 2014 Israel launched a seven-week military attack on the Gaza Strip. Over 2,000 Palestinians were killed, over 10,000 wounded, an estimated 500,000 were internally displaced, and enormous material damage led to an estimated cost of US $\$ 4$ billion for reconstruction and relief. ${ }^{2}$ However, during this military attack (called Operation Protective

${ }^{1}$ C. Miéville (2006) The Lies that Aren't Meant to Deceive Us, Socialist Review (November) Issue 311. Available at http://socialistreview.org.uk/311/lies-arent-meant-deceive-us, accessed August 15, 2015.

${ }^{2}$ See, for instance, the detailed report, United Nations Office for the Coordination of Humanitarian Affairs (UNOCHA 2014) Gaza Crisis Appeal: September 2014 Update. Available at http://www.ochaopt.org/doc- uments/gaza_crisis_appeal_9_september.pdf, and a similar report at http://www.unocha.org/aggregator/ sources/73?page=18, accessed August 15, 2015. 
$E d g e$ ), another war was taking place in cyberspace. These parallel clashes were not separate events, as each was an extension of the other. Countless images of the devastating military attack against Gaza dominated (social) media platforms, occasionally juxtaposed with scenes of large protests across the world. Due to huge advances in digital mediation, this kind of citizen journalism generated more visual material than ever before, archiving a Palestinian tragedy in blunt, yet poignant, detail. The wide dissemination of this content discomfited the mainstream media, provoking intense debates about Israel's media strategies. ${ }^{3}$ Did this war, with its huge destruction and casualties, which appears to have mobilized people across the world in opposition, signal a tipping point for Israel's public diplomacy? If so, did the internet play a crucial role in Israel losing the 'media war,' and how are the internet and mainstream media related? Digital technology plays a key role in the way that Israel projects itself internationally, and also in the ways in which Palestinians resist the Israeli occupation. The basic internet penetration rates for the occupied Palestine territories $(\mathrm{oPt})$ and Israel (60 and 90 percent, respectively) signify that online technologies are deeply embedded in both societies. ${ }^{4}$ Palestine was an early and enthusiastic adopter when the internet emerged in the Arab world, coinciding with the Second Intifada in 2000. ${ }^{5}$ Meanwhile, Israel's privileged IT development position and 'poster boy' status as a 'Start-Up Nation' confirms its world-leading position in the cyber warfare industry. ${ }^{6}$ Nevertheless, this position has not prevented critique.

Problems regarding Israel's reputation are not new. The state has faced strong criticism and public embarrassment during military campaigns in previous decades-most notably Lebanon in 1982, 1996 and 2006-and especially during Operation Defensive Shield (2002), when it instituted a violent military campaign in the West Bank during the Second Intifada. The years 2000-2005 also constituted a crucial period for the crystallization of online (and offline) anticolonial resistance: Events during this period delivered graphic images that became a part of peoples' collective memory, the impact of which went far beyond those directly involved, as illustrated elsewhere. ${ }^{7}$ Since 2005 , the emergence of blogging, user-generated videos, and social networking have all added to this development. ${ }^{8}$ The military campaigns in 2008-09 (Operation Cast Lead), 2012 (Operation Pillar of Clouds) and 2014 (Operation Protective Edge), which subjected Gaza to violent military campaigns, and

\footnotetext{
${ }^{3}$ Debates focused initially on how images from Syria were claimed to be from Gaza. However, as visual evidence from the war emerged, the issue then shifted from verifying sources to overcoming discomfort about the upsetting content itself. For discussions about the various competing social media claims, see R. Tooth (2014) Warning: Upsetting Images, The Guardian (G2), July 27, 2015; also see BBC special at https://www.youtube. $\mathrm{com} /$ watch?v=XnO4gy8dQIc debate, date of access; and Guardian contribution, http://www.theguardian.com/ commentisfree/2014/jul/21/sharing-pictures-corpses-social-media-ceasefire, accessed August 15, 2015.

${ }^{4}$ Most figures for the oPt cover the West Bank only, but it is expected that Gaza has higher numbers. For regional/ MENA statistics see: http://www.internetworldstats.com/stats5.htm, accessed August 15, 2015.

${ }^{5}$ See M. Aouragh (2011) Palestine Online (London: I. B. Tauris).

${ }^{6}$ D. Senor and P. Singer (2009) Start-Up Nation: The Story of Israel's Economic Miracle (New York: McClelland \& Stewart)

${ }^{7}$ M. Aouragh (2008) Virtual Intifada: Online Activism and Everyday Resistance, Journal of Arab and Muslim Media Research 1(2), pp. 109-130.

${ }^{8}$ For more on the changing media landscapes in Palestine and their social and political implications, see M. Aouragh (2011) Palestine Online; M. Sienkiewicz (2012) Out of Control: Palestinian News Satire and Government Power in the Age of Social Media, Popular Communication: The International Journal of Media and Culture, 10(1-2), pp. 106-118; L. Alsaafin (2013) Palestinians Turn to Facebook in Fight Against Occupation, Al Monitor. Available at http://www.al-monitor.com/pulse/originals/2013/04/social-media-palestinian-activism.html\#, accessed August 15, 2015.
} 
which have been widely condemned as constituting war crimes, ${ }^{9}$ are important moments in and of themselves. However, the fact that Gaza has been locked behind a land, sea and trade blockade since 2006 - thus having its economy strangled, its infrastructure destroyed, and its people impoverished-has contributed in particular ways to the degeneration of Israel's public image. This brutal context helps explains why the 2010 attack by Israeli forces on the Mavi Marmara flotilla, as it sought to break the blockade, generated extraordinary disapproval. In addition to the occasional condemnations in the official (diplomatic) arena, non-governmental organizations (NGOs) in Europe and North America have criticized Israel sharply in recent years. ${ }^{10}$ The barrage of negative responses to Israel's military confrontations has also provoked self-critique, and the nation's main public diplomacy strategy has become a popular target. Israel's State Comptroller published a damning report regarding the 2006 war on Lebanon. ${ }^{11}$ This critique led to the establishment of a government office dedicated to revamping Israel's diplomacy, a phenomenon commonly known as hasbara [Hebrew for 'to explain']. Despite novel developments and increasing international attention, hasbara is not a new phenomenon: it has always been regarded as a governing pillar of state politics. Rather than being a recent consequence of the internet, the perceived failures of hasbara are part of a recurring anxiety, one that has existed ever since the birth of hasbara during the founding of the State of Israel.

This article will argue that hasbara is best understood as the manufacturing of discontent with, or toward, Palestinian self-determination, while simultaneously constituting consent for Israel's dominance. However, set within conventional interpretations of public diplomacy, hasbara involves apparent ambiguities. After demonstrating the main hypotheses of public diplomacy, I propose that, having emerged within a (continuing) settler-colony, hasbara does not suit the general public diplomacy frame. Moreover, as media and journalism are key contemporary domains for public diplomacy, how, then, can social media be dealt with as recent, yet customary, platforms for journalists? I unpack this tension by discussing the presence of journalists on online digital public platforms, which have exposed the contradictions between Israel's desired and actual public persona. I then identify new forms of Israeli public diplomacy. The result is a rebooted version of hasbara: hasbara 2.0. This term has a double meaning: it both reflects the way hasbara has developed in response to social media, and also how it tries to adapt in response to shifting public opinion. Meanwhile,

\footnotetext{
${ }^{9}$ For outstanding reports that contain important evidence, see: UN General Assembly Human Rights Council (2009) Human Rights in Palestine and Other Occupied Arab Territories: Report of the United Nations FactFinding Mission on the Gaza Conflict. Available at http://www2.ohchr.org/english/bodies/hrcouncil/docs/ 12session/A-HRC-12-48.pdf; G. J. Wallance (2014) U.N. Human Rights Council's anti-Israel inquiry, Los Angeles Times. Available at http://www.latimes.com/opinion/op-ed/la-oe-wallance-gaza-unfair-un-resolution20140729-story.html; M. Cohn (2014) US Leaders Aid and Abet Israeli War Crimes, Genocide \& Crimes against Humanity. Available at http://jurist.org/forum/2014/08/marjorie-cohn-israel-crimes.php; A. Goodman and N. Shaikh (2014) As Palestinians Go to ICC, Human Rights Watch Alleges Israeli War Crimes for Shooting Fleeing Gazans, Democracy Now. Available at http://www.truth-out.org/news/item/25442-as-palestinians-goto-icc-human-rights-watch-alleges-israeli-war-crimes-for-shooting-fleeing-gazans; N. Cumming-Bruce (2014) U.N. Reports Dire Impact on Children in Gaza Strip, New York Times, August 5, 2014. Available at http://www. nytimes.com/2014/08/06/world/middleeast/un-reports-dire-impact-on-children-in-gaza-strip.html?_r=0>; http:// www.bbc.co.uk/news/world-middle-east-28437626; Save the Children (2008) The Gaza Strip: A Humanitarian Implosion. Available at http://www.savethechildren.org.uk/resources/online-library/the-gaza-strip-a-humanitarian-implosion, all accessed August 15, 2015.

${ }^{10}$ Molad (2012) Israeli Hasbara: Myths and Facts. Available at http://www.molad.org/images/upload/ researches/79983052033642.pdf, accessed August 15, 2015.

${ }^{11}$ The Annual Report $61 B$ (2010) by Comptroller (prepared by the Ministry of Foreign Affairs) is discussed in Molad (2012).
} 
online journalism offers content over which newsroom editors have less control, and it underwrites a particular information flow. Quite different from the artificial mediation of hasbara, this flow enables an affective relation between writer and reader. In due course, online media has an impact on the possibilities for Palestinian activists and international solidarity networks.

If accessible content-using the infrastructures of digital mass media as an active playground, rather than waiting to be heard-has the potential to influence part of the public, it may also solidify hasbara. For this reason, I explore the implementation of media hyperbole and red flags as short-cut routes for hasbara. These efforts clearly implicate potential Palestinian solidarity; however, while such policy of media distraction helps hasbara, they are not deterministic. In other words, while techno-media infrastructures contribute to transformations in the arena of diplomacy, the internal contradictions of diplomacy and media processes do not make them the sole mediators of news and opinion. Hasbara is under pressure as a result of the coming together of technological change, shifts in international public opinion and the rise of pro-Palestinian activism, and these are crucial factors in this dialectical process. Palestine reminds us that whereas the politically contentious context and changing media ecologies have diplomatic ramifications, they are never settled or constant.

\section{Deconstructing Hasbara}

An exploration of hasbara has to take place within debates and conceptualizations of diplomacy. There are two general approaches to public diplomacy: One that sees public diplomacy as a necessary evil; and another that sees it simply as a given context within which nations must interact. ${ }^{12}$ However, a literature review of Israeli diplomacy reveals that the idea of public diplomacy as a 'necessary evil' is more in tune with the Israeli approach to public diplomacy. Public diplomacy mostly is deployed with reference to a state's foreign (geopolitical or political-economy) policy; the basic premise of public diplomacy is influencing international (and sometimes domestic) publics. The perceived legitimacy of engaging in public diplomacy is based on the principle that antipathy to one's power may negatively affect the ability to pursue one's interests. While persuasion through public diplomacy is the contemporary paradigm, the case of Israel provokes a comparison with the less neutral term 'state propaganda,' (which can be understood as the communication of ideas to lure audiences in negative ways), that rather than persuasion typically refers to manipulation.

News management, public opinion and propaganda have long been related. Diplomacy has been transformed over the years so that earlier associations with totalitarianism have been refined into public diplomacy. Foreign policy decision-making is linked to newsroom decision-making. However, managing collective attitudes is mostly effective when it is unnoticeable because, in modern representative democracies, credibility rests on the assumed independence of the newsroom from political interests. ${ }^{13}$ Influencing the public is a process, crafted over time, the result of a form of negotiation. ${ }^{14}$ Public diplomacy is very often a product of, and a tool for, national security. ${ }^{15}$ The 'war on terror' signalled an important shift in public diplomacy, because the need to legitimize the wars in Afghanistan and Iraq

\footnotetext{
${ }^{12}$ N. Snow (2008) Rethinking Public Diplomacy, in: N. Snow \& P. M. Taylor (eds) Routledge Handbook of Public Diplomacy (London: Routledge), pp. 3-11.

${ }^{13}$ See further Z. Harb (2011) Channels of Resistance in Lebanon (London: I. B.Tauris), pp. 12-13.

${ }^{14}$ S. Saeed (2010) News Media, Public Diplomacy and the War on Terror, in: M. Zweiri \& E. C. Murphy (eds) The New Arab Media: Technology, Image and Perception (Reading, UK: Ithaca Press), p. 51.

${ }^{15}$ Ibid, p. 57.
} 
necessitated a return to Cold War styles of diplomacy. Nonetheless, 9/11 did not change the relationship forever: winning military wars does not depend as much on public opinion as on strength in the battlefield, as Saeed argued. ${ }^{16}$

The idea that the media are hegemonic has a longstanding legacy, going back at least to the model work of Walter Lippmann, which was the basis for the classic work by Edward Herman and Noam Chomsky. ${ }^{17}$ They explain that the media's filtering of reality leaves us with a clean residue that is fit for printing, one which is designed to pacify the public. Class conflict also is performed through mass media, because financial corporations own most media outlets and their news production effectively elevates dominant private interests. Citizens are inculcated with a set of values that fit the structures of society; in the process, dissent is marginalized. The 'propaganda model,' the term used by Herman and Chomsky to explain mass media, builds on the idea that bourgeois media reproduces capitalists' interests and offers valuable contributions. However, there are important reservations regarding the idea that 'the' media inculcate us with dominant values and beliefs. The alignment between the interests of capital and media do not offer fully adequate explanations. Dissenting voices are allowed, since there are differences between the media actors themselves, despite the fact that they share a capitalist framework. This was evident in the run-up to the Iraq war in the UK. ${ }^{18}$ The paradox is that capitalist media and news outlets function in a capitalist market system, and this means that they rely on customers (outlets must reflect at least some of their readers' interests) and they compete with other providers, which results in certain nuances in the dominant discourse. Hasbara also involves conflicting practices and strategies that are designed to improve Israel's reputation and to mobilize international public support, but it still deviates from public diplomacy. Following Edward Said, ${ }^{19}$ I regard hasbara as a state-orchestrated effort to manage the increasing public critique that Israel faces. Hence, to understand hasbara fully, we need to deconstruct public diplomacy further.

Public diplomacy is about gaining support for global and regional hegemony, it is far from not value free. Oddly, mainstream literature rarely explores the overall political and economic goals of public diplomacy (e.g., the advancing of free-market paradigms) and instead often employs normative terms, like 'rough states.' Unsurprisingly, public diplomacy is a US-focused topic in the literature, albeit (due to US global hegemony) one to which audiences and researchers across the world are predisposed. While analyses of public diplomacy are framed by ethical and humanitarian language, the management of imperial policy is the core motive of public diplomacy. ${ }^{20}$ The widely-cited Handbook of Public Diplomacy (Snow and Taylor 2008) is a case in point. ${ }^{21}$ Thus, the contradictions inherent in hasbara in part also reside within the general liberal imperial project that underpins many public diplomacy studies. In an excellent review of James Panment, ${ }^{22}$ Sue Jansen addresses the

\footnotetext{
${ }^{16}$ Ibid, p. 48.

${ }^{17}$ N. Chomsky \& E. Herman (1988) Manufacturing Consent: The Political Economy of the Mass Media (New York: Pantheon Books).

${ }^{18}$ See, for example, C. Sparks (2006) Contradictions of capitalist media practice, in: L. Artz, S. Macek \& Dana L. Cloud (eds) (2006) Marxism and Communication Studies: The Point is to Change it (New York: Peter Land), pp. 111-132.

19 See E. Said (2001) Propaganda and War, Media Monitors Networks, 31, August. Available at http://www.mediamonitors.net/edward37.html, accessed August 15, 2015.

${ }^{20}$ I. Hall (2010) The Transformation of Diplomacy: Mysteries, Insurgencies and Public Relations, International Affairs, 86(1), p. 249.

${ }^{21}$ Snow and Taylor (eds) Routledge Handbook of Public Diplomacy.

${ }^{22}$ J. Panment (2013) New Public Diplomacy in the 21st Century (London: Routledge).
} 
corporate predisposition of public diplomacy and points to the main flaw in much research: a focus on ideal scenarios, rather than on critically investigating the actual practices. ${ }^{23}$

Public diplomacy is distinguished from diplomacy mainly by the fact that it is geared toward the media and is interested in addressing the wider public. Overall, both diplomacy and public diplomacy studies identified $9 / 11$ as the moment at which a paradigm shift took place. ${ }^{24}$ As a result of this event, a return to unilateral and violent methods changed the context and shape of (public) diplomacy as a key instrument of foreign policy. This is reflected by problems of definition. ${ }^{25}$ Diplomacy is mainly a process of communication (as opposed to war), which is used to solve conflict or to maintain stability. ${ }^{26}$ Thus, while public diplomacy is, at its core, about how governments manage their position by promoting their national interests on a global scale, the way existing orders are justified depends on how they are positioned in a particular state structure. A relatively stable bourgeois democracy (e.g., Britain or the United States) will shape the content of dominant media differently and tends to meet the opinion of the public where it must. ${ }^{27}$ Such restrictions on the instrumentalization of mass media are reflected in diplomacy, albeit the extent of the limitation depends on a given historical context and depends also on which part of society is concerned: For instance, much of the careful restraints do not extend to particular minority groups.

After World War II and the processes of decolonization, and then the aftermath of the Cold War, imperialism and colonialism were not conditional on material (financial or military) superiority only: They depended more than before on the struggle for hearts and minds. Ideally, diplomacy relies on deterrence, rather than coercion, ${ }^{28}$ though a mixed approach (armed, economic and subversion) is the common reality. ${ }^{29}$ Public diplomacy therefore is treated differently from military-type operations (Psychological Operations [psyops]) and authoritarian-type propaganda. The main premise of public diplomacy is that it enhances state credibility by virtue of domestic and international behavior. This presents challenges with regard to the application of the term public diplomacy in Israel. Firstly, while hasbara alludes to a particular strategy of diplomacy, it is also part of a broader militarized context that inhibits military elements of psyop and cyber warfare. ${ }^{30}$ Again, the emphasis of public diplomacy is on soft measures, since voluntary legitimacy is more secure and sustainable than coerced obedience. Joseph Nye's much-used term 'soft power' corroborates the rationalization of non-violent/non-aggressive forms of submission. ${ }^{31}$ However, in this regard it is

\footnotetext{
${ }^{23}$ Among the contributors in Snow \& Taylor (eds) Routledge Handbook of Public Diplomacy, are diplomats, military personal and policy consultants. A bottom-up angle and assessment after policies are put in place would, for instance, disclose the resistance to public diplomacy offered by a number of practitioners. See S. Jansen (2013) Review - New Public Diplomacy in the 21st Century, E-International Relations, August 26, 2013. Available at http://www.e-ir.info/2013/08/26/review-new-public-diplomacy-in-the-21st-century/, accessed August 15, 2015.

${ }^{24}$ See, e.g., Panment, New Public Diplomacy; Snow \& Taylor (eds), Routledge Handbook of Public Diplomacy; B. White (2005) Diplomacy, in: J. Baylis, S. Smith \& P. Owens (eds) The Globalization of World Politics, 3rd edn. (Oxford: Oxford University Press).

${ }^{25}$ White, Diplomacy, pp. 387-403.

${ }^{26}$ Ibid, p. 388.

${ }^{27}$ Sparks, Contradictions of Capitalist Media Practice, p. 114.

${ }^{28}$ White, Diplomacy, p. 394.

${ }^{29}$ Ibid, p. 399.

${ }^{30}$ The link between political-economy and cybersecurity are very important to the ways cyber warfare and diplomacy are related in Israel. I discuss this elsewhere, in M. Aouragh (2015) Between Cybercide and Cyber Intifada: Technologic (dis-) Empowerment of Palestinian Activism, in: L. Jayyusi \& A. S. Roald (eds) Media and Political Contestation in the Contemporary Arab World: A Decade of Change (New York: Palgrave Macmillan), pp. $129-160$.

${ }^{31}$ J. Nye (2005) The Means to Success in World Politics (New York: Public Affairs).
} 
useful to remember Nye actually believed a combination of hard power (military force) and soft power (media strategies), that he named smart power, the ideal version. A difference between public diplomacy and hasbara is that, unlike public diplomacy, hasbara does not fit into a 'post-conflict' framework can't be 'smart'. This crucial disqualification becomes apparent in the results of its policies and renders hasbara susceptible to much critique.

\section{Trapped between Diplomacy and Propaganda}

Israel noticed a growing change in its international reputation during the Second Intifada. In the words of Eytan Gilboa, Israel was subjected to 'poisonous' and 'anti-Semitic' media coverage throughout Europe and the Arab world. ${ }^{32}$ Ever since this time the critique about Israeli public diplomacy has increased inside Israel. ${ }^{33}$ According to Gilboa, officials continuously 'failed to prevent the deterioration of Israel's image and reputation in the world. ${ }^{34}$ Israel began to pursue a more serious and confrontational diplomacy. ${ }^{35}$ Indeed, Israel's State Comptroller demanded an extensive examination of public diplomacy in 2002. Later, the conclusions of the Commission of Inquiry (into Israel's public relations during the war on Lebanon in 2006), which was known as the Winograd Commission, were no less damning. These criticisms were repeated even more loudly as a result of the negative impact (on Israel's reputation) of the 2008-2009 war on Gaza. Most Israeli reflections (to which I will return) argue that the problem is the lack of a proper public diplomacy policy, but taking into consideration the above review of public diplomacy, two important factors are ignored in these critiques. First, there is no shortage of public diplomacy in Israel. Second, this diagnosis confuses symptom with cure. This failure is the inevitable result of hasbara being an Israeli product, as the rest of this article will illustrate.

Whether assessed by its content or its targeted audiences, and inevitable exceptions aside, 'liberal democracies' are the epistemological basis of most public diplomacy analyses. This is why hasbara involves an inherent contradiction that is extremely difficult to overcome and which continues to destabilize its objectives. In a sense, to sanitize the grim realities of its colonial policies against Palestinians while ensuring consent within Israel, hasbara needs to fill the gap between rude propaganda and sophisticated psyops, on the one hand,

${ }^{32}$ E. Gilboa (2006) Public Diplomacy: The Missing Component in Israel's Foreign Policy, Israel Affairs, 12(4), p. 715.

${ }_{33}$ See T. Sheafer \& S. Shenhav (2010) Mediated Public diplomacy in a New Era of Warfare, The Communication Review, 12, pp. 272-283; Gilboa, Public Diplomacy; B. D. Mor (2006) Public Diplomacy in Grand Strategy, Foreign Policy Analysis, 2, pp. 157-176; R. Schleifer (2003) Jewish and Contemporary Histories of Israeli Hasbara, Jewish Political Studies Review, 15(1-2), pp. 123-153; M. Sherman (2013) Into the Fray: Dereliction of Duty, The Jerusalem Post, October 25, 2013. Available online at http://www.jpost.com/Opinion/Columnists/Into-The-Fray-Dereliction-of-duty-329723, accessed August 15, 2015. However distressing it is to read, at times, this Israeli body of work is helpful for two reasons: Firstly, it does not shy away from proclaiming its militaristic goals and Zionist ideology, unlike work that is framed as neutral yet which adheres to Israeli agendas; and secondly, the linguistic overlap with military terminology also suggests a (professional) background that is shared by the authors and the military, e.g., the reference to 'the enemy,' which, in this case, only can be the Palestinians (Schleifer, Jewish and contemporary histories, p. 123).

${ }^{34}$ Gilboa, Public diplomacy, p. 716

${ }^{35}$ This sudden shift in argument is only possible when ignoring the negative turn that was already visible in the 1980s, when Israel invaded Lebanon and was involved in the Sabra and Shatila massacre, followed by the crackdown on the non-violent mass civil uprising of the First Intifada. A telling reminder of the long legacy of hasbara is the quote by Abba Eban in The Jerusalem Post reproduced in the next section. 
and public diplomacy, on the other hand. It is within this conceptual mire that hasbara finds itself unable to make a clear shift: Communication, here a merciless tool in the service of settler-colonialism, mutilates the quintessential meaning of public diplomacy. It attempts to construct consensus through persuasion about its right to occupy and repress Palestinians. Yet, it does so while executing military campaigns in the oPt and maintaining segregationist policies for Palestinians inside Israel. As Taylor argued, when a nation goes to war, public diplomacy is forced to take a backseat and primacy is given to military doctrines. ${ }^{36}$ Israel's permanent front-seat is what gives rise to the hasbara stalemate. This tension will remain as long as Israel's Zionist, colonialist objectives remain. However, even if it suddenly wanted to, hasbara would not be able successfully to increase its moral authority-to make a 'post-conflict' shift—as that would undermine the Zionist project itself. This is why the words of Abba Eban from three decades ago, seem appropriate for the summer of 2014:

The immediate association in recent weeks has been the crash of steel against buildings, the screams of bereaved and wounded, the children lining up for water denied by an Israeli 'blockade', the rat-infested garbage heaps, the collapse of those thin layers of civility which shelter human beings against their own human vulnerability. It is little short of idiotic to believe that this movement of opinion could have been arrested by technical means such as a transfer of responsibility for 'hasbara' from one Cabinet desk to another. ${ }^{37}$

Interestingly, both the Western (liberal) and Israeli (Zionist) rationales share certain basic contradictions in relation to diplomacy. Aside from the clear Western-liberal double standards (non-violent democracy at home-whilst excluding minorities from this privilege-and violent warfare abroad), part of hasbara's own failing is the dysfunctional inheritance of Zionism. Tensions regarding diplomatic strategies are found across different ideological agendas because different Zionist tendencies became imperatives for public policy. ${ }^{38} \mathrm{As}$ Sasson Sofer shows, certain disparate perspectives in Israel's diplomacy are rooted in particular political traditions (for instance, David Ben-Gurion's Labour Zionism and Ze'ev Jabotinsky's Revisionism), which produced conflicting takes on the future state, and the divergence continued after 1948; in fact for Sofer, the intellectual foundation of Labour essentially caused later failures in diplomacy..$^{39}$ The idea that a certain Israeli diplomacy could be developed in a vacuum is a curious one, but the conclusion that an uncompromising rightwing approach would have made a difference is implausible. In a similar vein, the defining context of the 1948 war, or a Palestinian perspective, is completely absent in Zaki Shalom's

\footnotetext{
${ }^{36}$ P. Taylor (2008) Public Diplomacy and Strategic Communications, in: Snow \& Taylor (eds) Routledge Handbook of Public Diplomacy, p. 15.

${ }^{37}$ This quote refers to the summer of 1982; it was published in The Jerusalem Post and was retrieved by Ben White. The complete quote is reproduced in B. White (2013) Abba Eban's Comments on the Idiocy of Hasbara Just as True Three Decades Later, Electronic Intifada, February 18, 2013. Available at https://electronicintifada.net/ blogs/ben-white/abba-ebans-comments-idiocy-hasbara-just-true-three-decades-later, accessed August 15,2015.

${ }^{38}$ See Z. Shalom (2012) The Role of U.S. Diplomacy in the Lead-Up to the Six-Day War: Balancing Moral Commitments and National Interests (Brighton, UK: Sussex Academic Press); and S. Sofer (1998) Zionism and the Foundations of Israeli Diplomacy (New York: Cambridge University Press). Also, R. Schleifer (2011) Perspectives of Psychological Operations (PSYOP) in Contemporary Conflicts: Essays in Winning Hearts and Minds (Brighton and Portland: Sussex Academic Press).

${ }^{39}$ Sofer, Zionism.
} 
study. ${ }^{40}$ As noted by Laura Eisenberg, this view is devoid of context, aside from the trite use of the word 'terrorist. ${ }^{41}$ However, Ron Schleifer maintains that the reason for Israel's weak hasbara is that it is too soft, engaging too much with the 'clean' side. ${ }^{42}$ Elsewhere, Schleifer (2011) laments that hasbara is too concerned with defending itself, while it should be undermining the other-i.e., engaging in psyops rather than diplomacy-especially as Israel has far greater resources and an unrivalled security apparatus. ${ }^{43}$ Ben Mor, in contrast, proposed that 'impression management' must be a structural strategy, one that goes beyond mere damage control (which Mor sees as akin to hasbara). ${ }^{44}$

We see, therefore, a unique hasbara coming to life based on a meticulously engineered stigmatization of Palestinians. In an attempt to conceptualize this paradox of Israeli public diplomacy I borrow from Herman and Chomsky's critique of the corporate media in Manufacturing Consent, with the aforementioned reservation that complete manipulation of news is complicated by the contradictions of capitalism. Going further, as the evolution of public diplomacy itself shows, manufacturing consent by unabashed self-promotion and patriotic propaganda does not fit in our times. The alternative is to construct a narrative that questions the other. I therefore take note of the absence of Palestinian concerns in mainstream media, as was pointed out in Said's Peace and Its Discontents (1995) - the discontented themselves are not even consulted about their appraisal of 'peace' in this mainstream media. ${ }^{45}$ It is therefore as also important for Israel to generate discontent with Palestinians and their message. This results in the parallel, yet reversed, formulation of hasbara as representing the manufacturing of discontent. In other words, it assumes the employment of both elements (discontent-smear for the other, defend-promote the self).

\section{Hasbara at Work: Manufacturing Discontent}

Israel's formation of an informal Ministry of Hasbara, as part of the Foreign Ministry, in 2013, is testimony to the professionalization and intensification of hasbara, in terms of the amount of interventions (and subsidies) that result from it. This (policy) transformation responded to a number of key moments. Schleifer identifies one moment: the capture of two undercover Israeli agents in a police station in Ramallah in 2002. The photos of the agents' bodies being thrown out of a window (and a man holding up bloodied hands to cheering crowds) were the igniters of a pro-active hasbara.$^{46}$ This redirection went further under the influence of Prime Minister Benjamin Netanyahu and Foreign Minister Avigdor Lieberman, during their first coalition government.

One of the stark paradoxes that emerges from the many 'advisory' documents is that the suggested hasbara narratives - meant to increase pro-Israeli frameworks-are already close

\footnotetext{
${ }^{40}$ Shalom, The Role of U.S. Diplomacy.

${ }^{41}$ See L. Z. Eisenberg (2013) Review of Shalom, Zaki. 2012. The Role of U.S. Diplomacy in the Lead-Up to the Six-Day War: Balancing Moral Commitments and National Interests, Digest of Middle East Studies, 22(1), pp. 190-193.

${ }^{42}$ Schleifer, Jewish and Contemporary Histories, p. 124. By ‘clean' Schleifer means non-violent or within the limits of the law, which completely overlooks the violence of euphemisms used to cover-up colonial injustice. The 'apologetic Jew' - a 'weak and inferior Jewishness' with a 'Freudian longing' for acceptance-is described as lacking the wit to dispense Christian prejudice; this apparently has become a source for weak hasbara (p. 126).

${ }^{43}$ Schleifer, Perspectives of Psychological Operations.

${ }^{44}$ Mor, Public Diplomacy in Grand Strategy, p. 160.

${ }^{45}$ E. Said (1995) Peace and its Discontents: Essays on Palestine in the Middle East Peace Process (New York: Vintage Books).

${ }^{46}$ Schleifer Jewish and contemporary histories of Israeli Hasbara, p. 144
} 

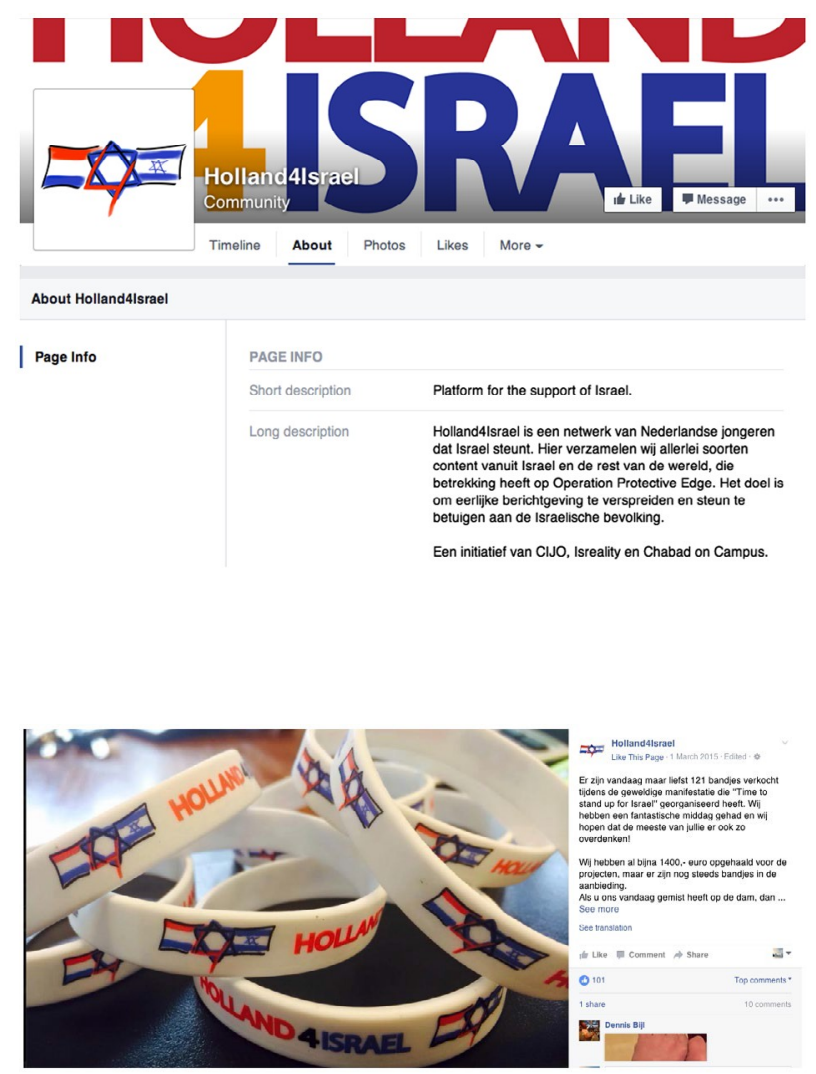

Figure 1. (a) Holland4Israel: Facebook; (b) Fundraising-paraphernalia in support of Israel.

to the general journalistic language. Decades of hasbara have nurtured and constructed a general language for, and interpretation of, Palestine/Israel. Essentially, this discourse is effective because Israel has crucial leverage with regard to powerful states (Great Britain and United States). Pro-Israel lobbies have developed into a transnational phenomenon, funded largely by transnational corporate actors, which, in turn, have incorporated them further into neoliberal and neoconservative networks. ${ }^{47}$ Thus the successes of the pro-Israel lobby are possible, not because of remarkably talented 'Jewish lobbies' (as often and wrongly is assumed), but because they coincide with certain material interests.

Online journalism, however, is an arena where news and opinion have become less monolithic. Coupled with particular realities on the ground, this has resulted in further contradictions. The occasional pro-Palestinian message or alternative report beyond the mainstream frameworks occur in spite of an internalized hasbara among journalists-because, overall, Western mass media already accommodate hasbara. As mentioned, rather than being evidence of an inherent

\footnotetext{
${ }^{47}$ H. Aked, T. Mills, T. Griffin \& D. Miller (2013) The UK's Pro-Israel Lobby in Context, Open Democracy, December 2, 2013. Available athttps://www.opendemocracy.net/ourkingdom/tom-mills-hilary-aked-tom-griffindavid-miller/uk's-pro-israel-lobby-in-context, accessed August 15, 2015.
} 


\section{国。}

IDF 0

Since tWorldCup began on June 12, terrorists in Gaza have fired 1000+ rockets at Israel. RETWEET so that all enjoying \#GERvsARG will know.

$12: 44$ p.m. - 13 Jul 2014
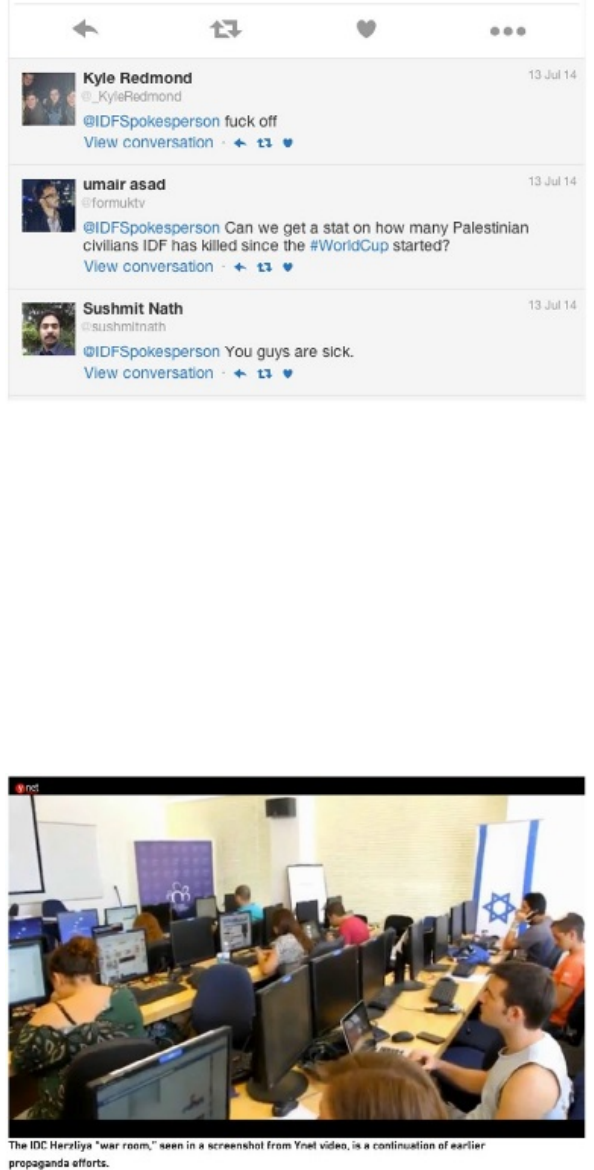

Figure 2. (a) IDF Twitter announcement GERvsARG hashtags; (b) Hasbara gathering as exposed by Electronic Intifada (courtesy of Ali Abunimah). 
openness in mainstream media, this is as a consequence of the ideological cracks provided by a liberal (capitalist) system or dominant frameworks. Such cracks sporadically are fi with relevant information. The 'both sides' paradigm is the sort of framing that assists hasbara most prominently in the mainstream domain. Before discussing the transformations of hasbara itself, we need to consider the kind of representations of Palestine/Israel it co-designs.

\section{'Suicide Bombers' and 'Hamas Rockets': The Politics of Red Flags}

\section{They answer the question, 'Did Israel kill the Ghalias?' when the question should be, 'What do we do about the fact that Israel killed the Ghalias?'48}

The archetypical 'two-sides' narrative, according to which all sides are wrong, or the truth is somewhere in the middle, is not instinctive: The aspect of Israeli military and political force first must be disentangled in order for it to become convincing. One of the contrivances is to replace the inequality that exists in terms of material and military power with moral trepidations. This may take the form of conflating the number of rockets fired from Israeli jets and warships with the number of Palestinian handmade grenades or stones. Another common form is the comparison between calling for revenge in Palestinian propaganda videos and actually committing military massacres. As a result impact is replaced by intent and this itself is pathologized and divorced from reason. In recent years, the term 'Hamas rockets' has become code for such a narrative. These discursive accommodations, above all, have allowed journalists and analysts to forget the daily structural living conditions.

A discomforting example occurred when, during the military attack on Gaza, a television host cut off a Palestinian guest: 'You had your chance. You didn't say Hamas is a terrorist organization. Good-bye.' ${ }^{49}$ Moreover, the term Hamas rockets is itself a continuation of the term 'suicide bombers': Such condemnation imperatives were prevalent in dominant media representations and academia during the Second Intifada, and led Ghassan Hage to ask,

why it is that suicide bombing cannot be talked about without being condemned first. After all, we can sit and analyse in a cool manner the formidably violent colonial invasion without feeling that 'absolute' moral condemnation should be a precondition or even a substitute for uttering an opinion about it..$^{50}$

Another common example of this kind of approach relates to the Palestinian 'failure' to commit to peace. The rejection of Israel's propositions - the result of the fact that this peace would bear no resemblance to justice and basically would prolong the suffering, since it would change none of the structural conditions-is rarely considered. This amounts, in a sense, to critiquing Palestinians for not accepting compromises and thus stripping the colonized of their dignity to be at least represented correctly.

\footnotetext{
${ }^{48}$ Miéville, The Lies that Aren't Meant to Deceive Us.

${ }^{49}$ This telling example of the systematic demand to condemn Hamas rockets during the 2014 war was illustrated by the appearance of a Palestinian-American director of the Jerusalem Fund on the Fox news show Hannity. As Munayyer explains that he does not want to discuss his personal opinion, but to debate the reasons behind these violent outbursts by militants, Hannity shouted: 'What part of this can't you get through your thick head?', before cutting Munayyer off. See the episode at https://www.youtube.com/watch?v=_FnV9Qc9MTY, accessed April 2015.

${ }^{50}$ G. Hage (2003) 'Comes a Time We Are All Enthusiasm': Understanding Palestinian Suicide Bombers in Times of Exighophobia, Public Culture 15(1), p. 71.
} 
By relating hasbara to these media practices, I aim to show that this is not simply the consequence of mass media-induced ignorance. For Hage, the condemnation imperative deliberately prevents a sociological explanation of why Palestinian suicide bombers act the way they do in the first place. In addition, this treatment then also muzzles criticism of existing international complicity. In this case, the difference between hasbara and public diplomacy is that it actually does not matter what Palestinians think, since hasbara initially is not designed to be believed by Palestinians. Unsurprisingly, since Palestinians, who have been resisting the occupying force for over a century, are an unlikely target, hasbara is mainly concerned with external influence. Its meta-goal is maintaining the international alliances that protect Israel through the provision of material and diplomatic support. Yet, when deconstructing the hasbara logic beyond this point, there is a message that is intended for Palestinians. Miélville's observation 'How, the world asked in incredulous rage, can they possibly think this ludicrous scenario will convince us? The answer, of course, is that they don't, ${ }^{, 51}$ with regard to the very coincidental shelling of a family on a Gaza beach in 2006 , explains this proposition. The hasbara referred to in this example is simply unconvincing, but the goal is meant to convey a reminder of the rules of engagement, namely that Israel indeed can do this and then keep 'the world' busy with ostentatious explanations. This kind of framing has become one of the most important aspects of hasbara and a recurring ritual. The outcome, as hinted at in this article's epigraph, is like many ceremonial formalities: It delays the actual question about what to $d o$ about it. The use of red flags indicates that the core purpose of hasbara is to distract from structural issues. Hence, besides having the objective of mobilizing international support for Israel, hasbara is meant to delay support for Palestinians and at the same time, to repair this settler-colonial omission. Suicide bombers smoothly transitions into Hamas rockets and become the bearer of the very narratives that manufacture discontent. This occurred most intensely after Operation Cast Lead and I therefore label it the 'cast doubt' approach.

\section{Hasbara 2.0: Operation 'Cast Doubt'}

State-led hasbara was nurtured under the tutelage of Daniel Seaman, Deputy Director General for Information at the Israeli Ministry of Public Diplomacy and Diaspora Affairs, followed by the Likud Member of Knesset (MK) Yuli Edelstein, after 2009. A social trend was already noticeable, as evidenced by the popular Israeli television show The Ambassador, in which contenders compete to mobilize support for Israel. ${ }^{52}$ The recruitment of multilingual Israelis as hasbara ambassadors is a case in point. The coordinated appeals to Israeli citizens to take an active part in media battles benefits from several state bodies. The Jewish Agency (historically concerned with settling Jews on Palestinian land), provides data about new Jewish immigrants, and the Immigrant Absorption Ministry enables the recruitment of large numbers of multilingual volunteers. ${ }^{53}$ Israel's airline company, El Al, even experimented

\footnotetext{
${ }^{51}$ Miéville, The Lies that Aren't Meant to Deceive Us.

${ }^{52}$ The normalization of hasbara through this hugely popular program revolves around a competition between hasbarists, battling to represents Israel; see C. Urquhart (2004) Our Man in the US: Israel uses TV show to Find its best Spin Doctor, Guardian, November 27, 2004. Available at http://www.theguardian.com/world/2004/ nov/27/israel1. The programme was supported by a variety of political organizations (e.g., see Hillel International (2006) Vote for Israel's next 'Ambassador' to the United States, Hillel International News and Views - Blog. Available at http://www.hillel.org/about/news-views/news-views---blog/news-and-views/2006/02/24/vote-forisrael-s-next-ambassador-to-the-united-states-, accessed August 15, 2015.

${ }^{53}$ In particular, the hiring of Avi Mayer as a new media specialist resulted in a new style of diplomacy online; see, e.g., http://www.jewishagency.org/blog/1/article/58, accessed August 15, 2015.
} 
with an offer of special allotted paydays for flight attendants in the United States to engage in personal hasbara. These $\mathrm{El} \mathrm{Al} \mathrm{Ambassadors} \mathrm{use} \mathrm{their} \mathrm{free} \mathrm{slots} \mathrm{between} \mathrm{flights} \mathrm{to} \mathrm{engage}$ in small talk with local residents, sharing personal stories about living in Israel, while mentioning Israel's success in the fields of science and culture. ${ }^{54}$ The recruitment of volunteers was achieved most prominently through enlisting support from Israel's biggest student union, in 2013. ${ }^{55}$ In times of war, full-time social media operatives are formed in what is referred to as war situation or operation rooms, to engage in political astroturfing (see Figure $2 \mathrm{~b}$ ). ${ }^{56}$

Transnationally coordinated efforts and the use of multilingual Israelis reflect some of the most far-reaching evolutions in hasbara. The period immediately after the outbreak of the Second Intifada (which coincided with the 'War on Terror') saw the creation of what is termed 'neoliberal Zionism. ${ }^{57}$ As mentioned, these overlaps exist because capitalists and Zionists share some of the same ruling class networks. The pro-Israel lobby groups are supported by, and intimately connected with, pro-Israel Christians. ${ }^{58}$ In the Netherlands, hasbara volunteers are found within evangelical groups with a Zionist affinity. Their networks are the Facebook group and the Twitter account Holland4Israel. As events in 2014 show, they come together and tap into numerous virtual platforms to target pro-Palestine activists. However, they do not engage randomly: They adhere to well prepared and mostly discursive campaigns. The attention given to language is therefore crucial.

The 2009 Global Language Dictionary report by The Israel Project advises how to instrumentalize hasbara volunteers better. ${ }^{59}$ The report documents the methods that lie behind the meticulously organized media hasbara and confirms Israel's move to a positive (soft) discourse by demonstrating which language should be deployed to advance the pro-Israel paradigm. It gives an example of how to counteract the 'right of return' (enshrined in UN General Assembly Resolution 194) by re-framing it as an unreasonable Palestinian 'demand' that is blocking peace efforts. This political recalibration is designed to reinforce the sense of the conflict being complicated. The report warns against declarative statements (every, totally, always and never) because 'westerners think in shades of grey. ${ }^{90}$ Another prominent pressure group, Yisrael Sheli [My Israel], also recommends against being argumentative

\footnotetext{
${ }^{54}$ See the announcement and list of participants here: http://embassies.gov.il/new-york/SpeakersBureau/Pages/ El-Al-Ambassadors-.aspx, accessed August 15, 2015.

${ }^{55}$ See also B. Ravid (2013) Prime Minister's office Recruiting Students to Wage Online Hasbara Battles, Haaretz, August 13, 2013. Available at http://www.haaretz.com/news/national/.premium-1.541142, accessed August $15,2015$.

${ }^{56}$ See Corporate Watch (2012) Corporate Watch Magazine \# 52, Spring/Summer 2012, for a clear explanation of the main idea behind 'astroturfing,' a term that refers to fake green grass to point at the fake endorsements of products: https://corporatewatch.org/magazine/52/springsummer-2012/online-astroturfing, accessed August $15,2015$.

${ }^{57}$ Aked et al., The UK's pro-Israel Lobby.

${ }^{58} \mathrm{See}$, for instance, Christians For Israel International. Available at http://www.c4israel.org/c4i/about_us/offices.

${ }^{59}$ The report was leaked to Newsweek: http://www.newsweek.com/2009/07/08/the-israel-project-s-2009-global-language-dictionary.html., accessed March, 2010. The manual claims to be informed by polls and focus group experiments, although it presents no indications of methodological evidence. A number of investigative journalists have been tracking such hasbara projects, see: M. Blumenthal (2013) Israel Cranks up the PR Machine, The Nation, November 4, 2013; M. Leas (2010) Delegitimizers of Israel, Counterpunch, May; R. Silverstein (2009), Hasbara Spam Alert, The Guardian, January 9, 2009. The consistent reporting by Electronic Intifada and Mondoweiss is also very helpful.

${ }^{60}$ The report also found that certain words - accountability, children, diplomacy, prosperity, prevention, perseverance-or general references_-Hamas or militant Islam instead of Palestinians-work better.
} 
and realizing that there is a democratic community to be taken into consideration. ${ }^{61}$ They specifically target American liberals (Democratic Party voters) and differentiate party cadres (on which it can rely) from passive voters (more open to critique), who are not necessarily pro-Israel. Indeed, hasbara reports focus on the American public, for the obvious reason that they are, as US taxpayers, the main external funders of Israel, given that Israel is the recipient of the largest amount of US foreign spending. These recommendations clearly disclose where hasbara imagines its audience to exist, but it also is important to read them as evidence that hasbara is being forced to cope with a globally changing public-one that rejects war, apartheid and land appropriation. These reports have a distinctively corporate tone, and borrow from the formula of 'viral marketing.' A good example of this marketization of hasbara is Brand Israel. ${ }^{6}$

Hasbara volunteers manipulate facts or make unfounded accusations of anti-Semitism, ${ }^{63}$ and thus operate in a manner that is referred to as 'trolling.' They create public fronts from behind which they can attract supporters with affirmative sentiments. Whether in Amsterdam or Tel Aviv, the formula is the same: A group of volunteers and coordinators come together and produce information outlets that disseminate resources and repetitive views via online groups. This signals the emergence of hasbara as a more belligerent form of Israeli public diplomacy, e.g., the manipulation of images through digital Photoshopping (altering the texts on placards carried at demonstrations, from 'Stop Israeli Terrorism' to 'Stop Hamas Terrorism on Israel'), or attributing pro-Israeli quotes to famous historical figures, such as Martin Luther King. ${ }^{64}$

Taken together, the policy reports, instructions and commercial strategies constitute a form of public relations and crowd-sourcing that are at once diplomatic and corporate. Such astroturfing and branding varies from selling plastic bracelets to expressing positive reactions through supposedly random posts, and they all can be mediated through the supposed neutral (apolitical) language of tourism or sports. ${ }^{65}$ For instance, during summer, 2014, Twitter followers of the Israel Defense Forces (IDF) were asked to re-tweet its posts with the additional hashtag \#WorldCup in order to maximize reach (Mackey 2014). ${ }^{66}$ The essential point to note here is that the methodologies rely chiefly on internet infrastructures. In recent

${ }^{61}$ Yisrael Sheli made one of the most outstanding interventions by organizing seminars teaching how to edit online content in favor of Israel, for a report of such a gathering see: https://www.youtube.com/watch?v=t52LB2fYhoY. See also: http://www.webelieveinisrael.org/ where similar assistance and model letters are offered. Accessed August 15, 2015.

${ }^{62}$ R. Hassman (2008) The Israel Brand: Nation Marketing under Constant Conflict. Available at http://spirit.tau. ac.il/government/downloads/Rommy_Hassman_HebBLINT.pdf, accessed August 15, 2015.

${ }^{63}$ C. Liphshiz (2014) From Dutch Situation Room, pro-Israel Volunteers Defend Jewish State on Social Media, Jewish Telegraphic Agency, July 29, 2014. Available at http://www.jta.org/2014/07/29/news-opinion/world/ in-dutch-situation-room-pro-israel-volunteers-defend-jewish-state-on-social-media, accessed August 15, 2015

${ }^{64}$ See F. Kiblawi and W. Youmans (2015) Israel's Apologists and the Martin Luther King Jr. Hoax, Electronic Intifada, August 15, 2015. Available at http://electronicintifada.net/content/israels-apologists-and-martin-lutherking-jr-hoax/4955, accessed August 15, 2015.

${ }^{65}$ On rare occasions, people also coordinate offline efforts, such as pro-Israel (counter-) demonstrations. In this case $€ 1400$ was made selling 121 plastic bracelets in Dam Square in the capital city Amsterdam. It is important to note that this step was in response to three successive large pro-Palestinian demonstrations throughout the country. The Facebook group can be found at https://www.facebook.com/Holland4Israel/info?tab=page_info and the Twitter account at https://twitter.com/Holland4Israel, last accessed August 15, 2015.

${ }^{66} \mathrm{Cf}$. A. Mohammed (2014) Moeen Ali and the Language of War and Protest, Islam 21C, August 18, 2014. Available at http://www.islam21c.com/politics/moeen-ali-and-the-language-of-war-and-protest/, last accessed August 15, 2015. 
years, many examples of this hasbara genre have converged with social media. As I will discuss in more depth now, a greater intimacy began to develop between state bodies, hasbara projects and military campaigns. Hence, efforts to convince the international mainstream media that Palestinian stones are as bad as Israeli warplanes are intensely mediated through online videos. ${ }^{67}$ Furthermore, social media, often the first outlet for breaking news, potentially can weaken government interference or newsroom control. This is the double meaning of hasbara 2.0: the idea being that cyberspace is where a new public needs to be challenged.

\section{The Emergence of Hasbara 2.0}

We have to understand, first of all, and identify the problem that we are facing a very dedicated enemy who is also very sophisticated and who is now also using technology: Internet, Facebook and many many other things; using NGOs in a very sophisticated way and a large network... there is a dedicated campaign against us by a whole network. ${ }^{68}$

If one takes the scale, recruitment and training of those employed in hasbara activities as a measure, then it is clear that a sense of urgency affected Israel between 2008 and 2012. Hasbara 2.0 therefore arose in response to two mutually constitutive shifts: First, on a conceptual level, deciding whether hasbara was to be the aggressive propaganda variant or the subtle public diplomacy version; and, second, on a technical level, updating its tools (from Web 1 to Web 2) and practices (relying on an army of volunteers) related to what came to be framed as the emergence of hasbara 2.0, or digital diplomacy.

Israel's international reputation had experienced serious damage during the 2006 Lebanon war, and Operation Cast Lead two years later, proved to be the main turning point. This military confrontation particularly heightened the international solidarity movement with Palestinians and it facilitated a change in international public perceptions of Israel. The many graphic images of people escaping bombardment or covered in detritus, video footage of injured or dead children, the (self-) portraits of IDF soldiers admitting to the killing of children that were circulated on YouTube, Facebook and Instagram and were beamed directly to publics across the world, all had a huge impact. During this period of intense violence, mainstream media outlets became more critical and thus a different approach from Israel was required. Israel therefore felt it had to adopt a more assertive hasbara strategy in response. More guidelines appeared, which urged a move away from an aggressive propagandist variety of hasbara, and instead recommended a more subtle variant. Yet, it cannot be denied that this was first and foremost a war in cyberspace that was fought over real events. The increased levels of hasbara came in response both to real events themselves and to pro-Palestinian activism around these events.

This occurred, for instance, during the 2010 attack on the Mavi Marmara aid flotilla, and during the November 2012 war (Pillar of Clouds) on Gaza, as well as the July-August

\footnotetext{
${ }^{67}$ Apart from external influence, one can also read these hasbara videos as simultaneously communicating to Israelis that they are stronger and are winning, i.e., do not need to question their colonial policy. Besides the motive of distracting them from the 'real issues', announcing intent for Israelis themselves is thus an important parallel motive in much of the hasbara propaganda.

${ }^{68}$ Deputy Foreign Minister Danny Ayalon (2010). See full talk at https://www.youtube.com/watch?v=06gjuYT7eMU, accessed August 15, 2015.
} 


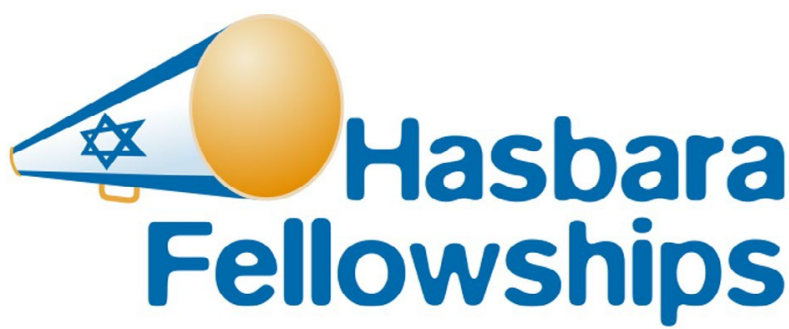

Empowerment. Community. Strategic Impact.

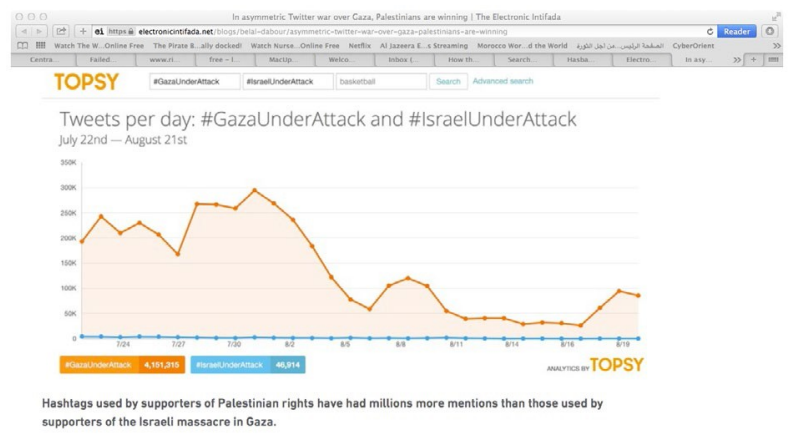

Figure 3. (a) Campus based campaigns are funded by special fellowships; (b) Pro-Palestinian tweets compared to pro-Israel tweets with similar hashtag (courtesy Linah Alsafinah).

2014 war on Gaza. ${ }^{69}$ These hasbara campaigns thus mushroom in tandem with high levels of pro-Palestinian online activism. As a result, the levels of digital hasbara during these military assaults was intense. ${ }^{70}$ Simultaneously, these technological efforts aligned more strictly with 'operational' matters, i.e., they took place at the heart of the military. After the Mavi Marmara incident, the IDF launched its own blog, Twitter account and YouTube channel. IDF Lieutenant Aliza Landes, who was the first to initiate these activities, noted that the mainstream media often taps into microblogging spaces and online video channels and made clear that providing visual mediation was therefore indispensable. ${ }^{71}$ The YouTube channel had videos of successful army defences against Palestinian and Lebanese attacks during the 2006 war on Lebanon. However, its popularity really soared during Operation

\footnotetext{
${ }^{69}$ It is outside this article's scope to discuss the impact of new media on grassroots politics in Palestine. For an extensive analysis see Aouragh, Virtual Intifada; E. Siapera (2013) Tweeting \#Palestine: Twitter and the Mediation of Palestine, International Journal of Cultural Studies, 17(6), pp. 539-555. doi: 10.1177/1367877913503865; A. Najjar (2010) Othering the Self: Palestinians Narrating the War on Gaza in the Social Media, Journal of Middle East Media, 6(1), pp. 1-30.

${ }^{70}$ B. Makuch (2014) Israel is Outgunning Hamas on Social Media, Too, Motherboard Vice, July 25, 2014. Available at http://motherboard.vice.com/read/israel-is-outgunning-hamas-on-social-media-too, accessed August 15, 2015; D. Kerr (2014) How Israel and Hamas Weaponized Social Media, CNET, January 13, 2014. Available at http://www.cnet.com/uk/news/how-israel-and-hamas-weaponized-social-media, accessed August 15, 2015; H. Sherwood (2014) Israel and Hamas on Social Media, Guardian, 16 July, 2014. Available at http://www. theguardian.com/world/2014/jul/16/israel-hamas-clash-social-media, accessed August 15, 2015.

${ }^{71}$ For interesting reportage, see R. Aren (2010) available at http://www.haaretz.com/weekend/anglo-file/1.296914, accessed August 15, 2015.
} 
Cast Lead, when it momentarily became the second most subscribed channel of YouTube, according to Jonathan Cook, in the first week of the war, a period that also coincided with the first systematized outsourcing of Twitter. ${ }^{72}$ Lieutenant Sacha Dratwa followed in Landes' footsteps as head of the New Media Desk. ${ }^{73}$ Trained in this new field during Cast Lead, Dratwa pushed the IDF's involvement in the 'media war' even further by coordinating many of the real-time online campaigns. Being a native French speaker he also led the Francophone online interventions. During the attack on the Mavi Marmara, English subtitles and captions helped to create certain interpretations that delegitimized the Palestinian narrative. ${ }^{74}$

By 2012 these hasbara-style initiatives from the IDF were synchronized as an interactive online branch that came under a new command, with a permanent team operating in liaison with the Ministry of Hasbara, and in liaison with international volunteers, as mentioned before ${ }^{75}$ According to the IDF's social media chief, Avital Leibovich, 'The military is a closed organization, it doesn't share with other people - it uses harsh language. Here we are exactly the opposite, we are creative, we are open, we are interacting, and we are sharing. This is something very unique. ${ }^{76}$ The Israeli army was learning how to benefit from the new media ecology, largely because of the innovations of its young conscripts. Indeed, as she continued, 'These [soldiers] are 19-year-olds! They've grown up with this technology and have integrated it—internalized it—completely. ${ }^{, 77}$ Hasbara had to adjust to digital media because online media is not as impassable as the comfort-zone of the mainstream media. However, the issue is not that the mainstream press finally have ceased to ignore the Palestinian side of the story, or that journalists have become more aware and resistant to Israeli spin doctors per se.

Israel's behavior and subsequent image as a military aggressor increased just as social media (especially Twitter) began to reconstitute journalism. We saw this most clearly during reporting about the war on Gaza in 2014. The combined effect of the physical presence of journalists (and therefore potentially more personal) and being embedded in Twitter, that operate outside the official media's confines, suggests that social networking media offer a different algorithmic logic of news mediation. Discussing the incorporation of Twitter into news discourses, Zizi Papacharissi and Maria Oliveira also suggest that the rhythms of journalistic storytelling have changed. ${ }^{78}$ They maintain that, during the first few months of

${ }^{72}$ J. Cook (2009) Internet Users Paid to Spread Israeli Propaganda, The Electronic Intifada, July 21, 2009. Available at https://electronicintifada.net/content/internet-users-paid-spread-israeli-propaganda/8355, accessed August 15, 2015.

${ }^{73}$ Typical of the 'start-up nation's secret of success, Dratwa began an online marketing and public relations firm, which gave him additional experience, scope and clients. See J. Urich (2011) Meet the Head of the IDF's New Media desk, Israel Defence Forces, June 27, 2011. Available at http://www.idf.il/1398-12231-en/Dover.aspx, last accessed August 15, 2015.

${ }^{74}$ Kuntsman \& Stein 2010; D. Allan \& C. Brown (2010) The Mavi Marmara At the Frontlines Of Web 2.0, Journal of Palestine Studies, 40(1), pp. 63.

${ }^{75}$ While it was named 'Pillar of Clouds' in Israel, for Western media the less harsh sounding name 'Pillar of Defence' was used. For Palestinians, it was a military operation that killed almost 500 Palestinians.

${ }^{76}$ M. Borgstede (2013) Tweet Offensive: Social Media is Israeli Military's Newest Weapon, Worldcrunch, 21 July, 2013. Available at http://www.worldcrunch.com/culture-society/tweetoffensive-social-media-is-israeli-military-039-s-newest-weapon/israel-tsahal-social-media-idf-avital-leibovich-hamas-hezbollah/c3s12783/\#.U-jwgBZeNG5, accessed August 15, 2015

${ }^{77}$ Ibid.

${ }^{78}$ Z. Papacharissi \& M. Oliveira (2011) The Rhythms of News Storytelling on Twitter: Coverage of the January 25th Egyptian Uprising on Twitter. Paper presented at the World Association for Public Opinion Research Conference, Amsterdam, September 2011. Available at http://www.researchgate.net/publication/264645964_Affective_ News_and_Networked_Publics_The_Rhythms_of_News_Storytelling_on_Egypt, last accessed August 2015. 
the Arab uprisings, Twitter built on a stream of news that mainly had affective content. The suggestion is that such online (affective) mediated news streams are more in tune with spontaneous inputs and therefore also more susceptible to emotional connections. For instance, 'breaking news' is an additional mechanism underlying these rhythms, temporarily affording online reports the possibility of becoming news stories in themselves. However, it also could be the case that instant Twitter feeds are added as part of the reporting stream when access to the field is blocked and, at the same time, there is increased pressure on editors to report from the ground (as is common in the increasingly competitive news sector).

While this is indeed relevant for consideration, we cannot simply extrapolate this to journalism on Palestine/Israel, a topic that is considerably less open for debate. Reporting about Palestine is more complex and less fair, ${ }^{79}$ and so offers limited space for a news ecology that is geared toward positive rhythms based on affect, as suggested by Papacharissi and Oliveira. ${ }^{80}$ It is more likely that when access is blocked by Israel, editors still will not promote informal Palestinian voices to fill the gaps, as it did with various Arab bloggers in 2011. In other words, the fissures offered by these rhythms will be very exceptional for Palestine. But what if this exception is presented with an all-out war? And what does this suggest in terms of the visual material it bestows? Military attacks create violent images: Uncensored footage sometimes even is recorded by journalists themselves as they happen to witness attacks first hand, and on occasion they are beamed into living rooms through digital platforms. As journalists also utilize social media platforms, their content may become part of grassroots information flows. This occurred briefly in the summer of 2014.

\section{Online Journalism: A Reckoning?}

Many journalists are embedded in microblogging platforms, and they generally have a large number of followers. Their presence in situ offers the viewing public a direct window on conditions on the ground, as they share their observations. These journalists may witness exactly what happened before or after a bombing; reactions to this, a human response that comes with the repugnancy of witnessing violence, becomes a liability. Yet when they share this observation through an instant medium that is outside central editorial control, this has direct implications for Israeli public diplomacy efforts. In their raw and uncensored manner, the reality of the experience of the journalist is portrayed. This process begins to explain why the sleek and well-prepared hasbara content does not generate the same conviction. For example, CNN's Diana Magnay's aversion was visible as she reported from a hilltop full of Israelis cheering the bombings of neighbourhoods in Gaza. Or the case of Peter Beaumont, who described how he witnessed an Israeli naval shelling ripping apart four children playing football on a beach: His shock is deeply ingrained in his comments on Twitter and in a piece for The Guardian newspaper. NBC's Ayman Mohye ldin also

\footnotetext{
${ }^{79}$ G. Philo \& M. Berry (2011) More Bad News from Israel (London: Pluto Press); D. Baram (2004) Disenchantment: The Guardian and Israel (London: Guardian Books); and A. Bishara (2013) Back Stories: U.S. News Production and Palestinian Politics (Palo Alto: Stanford University Press).

${ }^{80}$ Papacharissi \& Oliveira, The Rhythms of News Storytelling on Twitter.
} 
covered the same incident, recording the mothers and fathers of these children just as they realized what had happened. ${ }^{81}$ The response of these journalists, infused with a sense of indignation, becomes part of the news story itself, and, in turn, they are shared even more widely through their linked platforms.

In other words, the reporting by journalists in the summer of 2014, together with a far greater online presence, created a disconnect between Israel's hasbara message and what was being reported. The fact that these are mostly journalists operating inside mainstream media networks causes deeper cracks in the centre of the fault lines, with the subsequent potential to create greater fracturing of the hasbara vision. Israeli spokespeople had great difficulty explaining the situation..$^{82}$ In such cases hasbara efforts are intensified. Nevertheless, even the best versions of hasbara, applied with maximum effort, have difficulty legitimizing a militarily superior entity that is launching tank bombardments and airstrikes against a confined population. With some of the extraordinary events instantly flashed through online networks, it has become harder to contain contradictory messages. At this point hasbara is at its weakest: As it reveals itself, its distortions become almost predictable. In such a high profile context, a corporate-style foundation for hasbara does not always succeed in its appeals. It is also more likely to be rejected during moments of (humanitarian) crisis. However, Israel is also challenged by pro-Palestinian narratives, due to the competitive nature of corporate media and the changing techno-social infrastructures, as argued at the outset. Such critical analyses help us to account for the apparent anomalies of Israeli public diplomacy, and in due course they also may help us to shed light on the ongoing struggles, and to challenge the dominant power relations in the context of the media's changing position. The development of the internet has helped to change the political order and the balance of forces. I do not mean by this that politics can be deduced from technology, but, rather, I highlight their interconnectedness. The result is a techno-political dialectic that comes from both sides, from technological changes and a growing political consciousness. For mass media are an important source of information and opinion. At the same time, external dynamics (such as an influential protest movement) also can produce particular ideas that push against the dominant media framings ${ }^{83}$ Parallel to this important dynamic, there are also changes in the infrastructure that allow those contesting ideas to be mediated more widely. Access to mass media is necessary in order to set the agenda and, if possible, to cultivate it as a free space; a space to which to (re)direct attention. This is where critical writings on the temporary synchronization between revolutionary activists' agendas and mainstream journalism, such

\footnotetext{
${ }^{81}$ Magnay tweeted about being harassed and called the Israelis on the hilltop 'scum.' She was removed from Palestine by her employer and sent to Moscow, provoking mocking comments about her being sent to Siberia. Mohyeldin commented about this on Facebook. He also was pulled out, presumably in response to his personal comments on Facebook. He was reinstated after a big outcry by fans and colleagues. Beaumont tweeted about having seen a father scraping up his son and putting the pieces into a plastic bag. See, respectively: M. Calderone (2014) CNN Removes Reporter Diana Magnay from Israel-Gaza after 'Scum' Tweet, Huffington Post, July 18, 2014. Available at http://www.huffingtonpost.com/2014/07/18/cnn-diana-magnay-israel-gaza_n_5598866. html; G. Greenwald (2014) NBC pulls veteran reporter from Gaza after witnessing Israeli attack on child, The Intercept, July 17, 2104. Available at https://firstlook.org/theintercept/2014/07/17/nbc-removes-ayman-mohyeldin-gaza-coverage-witnesses-israeli-beach-killing-four-boys/; P. Beaumont (2014) A father opens a plastic bag: 'This is my son', he says, killed by an Israeli shell, Guardian, July 18, 2014. Available at http://www.theguardian. com/world/2014/jul/18/father-gathers-body-dead-son-two-plastic-bag-gaza-shelling, accessed August 15, 2015.

${ }^{82}$ Israel's chief spokesman for the country's Prime Minister, Mark Regev, normally is allowed to out-talk his opponents, but during a Channel 4 interview by Jon Snow there was a confused and irritated look on his face: https://www.youtube.com/watch?v=M_-76H-YRjs, accessed August 15, 2015.

${ }^{83}$ Sparks, Contradictions of Capitalist Media Practice, p. 130.
} 
as during the 2011 Arab uprisings, can help. ${ }^{84}$ They remind us that volatile occasions give rise to more debate and opposition.

Indeed, when pushing too far, Israeli hasbara practices cause more damage. When asked to support a propagandist Facebook page that promotes Israeli tourism, while the ugliness of war is intensely mediated, hasbara astroturfing is unlikely to strike an emotional chord. On the contrary, it may lead to unforeseen results, such as inadvertent comments about the Israeli army, and thus it may become belligerent. Pressure from below can bring about a momentary synchronization of news and political dynamics. This article insists on the interface between the journalistic social media ecology and pro-Palestinian activism. Together they can reach and influence public opinion, as the next, and final, section of this article suggests.

\section{Implications for Palestinian Solidarity}

As mentioned, the notion of media 'neutrality' is especially necessary in 'representative' democracies, and this makes it also more vulnerable to pressure. Pro-Palestinian involvement (both online and offline) is therefore an indispensable part of the dynamic. Although often ignored by media or public diplomacy experts, it is necessary to pay attention to political resistance in order to obtain a full picture. When activists mobilize on a large scale, they can persuade sections of society. Precisely because it is not useful to provide a forensic assessment of hasbara activities for their own sake, I do so with this tension in mind.

A materialist concept of media and communication technologies recognizes the dialectical contradictions in its unsettled and dynamic social reality. For that is also why the relationship between mainstream media and the political and economic élite reflects a greater overlap with Zionist pressure groups than with ordinary people, who are neither élite nor necessarily pro-colonial. This contradiction suggests an antagonism that in itself can be the basis for struggle and progress ${ }^{85}$ This does not mean that the mere existence of oppression is sufficient to achieve resistance. Dana Cloud, for instance, explains this through the difference between class as an objective entity, and class as a subjective consciousness. ${ }^{86}$ Changing political awareness inevitably will require mediation, and while attempts to change such awareness indeed often are tried through the media, they also can take place through activism. The rhetorical power of a social movement can disrupt business as usual. ${ }^{87}$ That is why I have argued that hasbara is not merely challenged technologically.

During contentious moments in recent years-from disrupting propaganda efforts to the imposition of alternative media frameworks, Israeli hasbara faced an increasingly successful counter-narrative. This occurs despite the fact that dominant media frameworks helped to manufacture an erroneous framework over several decades, always ready for hasbara to exploit. As noted, this is denoted most clearly by the 'both sides' imperative, and its exasperating red flags. The small victories are the product of a political process that evolves the combined effect of technological tools and political activism. In this way new media

\footnotetext{
${ }^{84}$ This argument is developed in greater detail in A. Alexander \& M. Aouragh (2011) The Egyptian Experience: Sense and Nonsense of the Internet Revolution, International Journal of Communication, 5, pp. 1344-1358; and A. Alexander \& M. Aouragh (2014) Egypt's Unfinished Revolution: The Role of the Media Revisited, International Journal of Communication, 8, pp. 890-915.

${ }^{85}$ L. Artz (2006) On the Material and the Dialectic: Toward a Class Analysis of Communication, in: L. Artz, S. Macek \& D. L. Cloud (eds) Marxism and Communication Studies.

${ }^{86}$ D. L. Cloud (2006) Change Happens: Materialist Dialectics and Communication Studies, in: L. Artz, S. Macek, D. L. Cloud (eds) Marxism and Communication Studies, pp. 62-65, provides an interesting reflection of the different takes on the extent of the spontaneity of consciousness between Lukacs, Luxemburg and Gramsci.

${ }^{87}$ L. Artz, On the Material and the Dialectic, p. 46.
} 
strategies can converge the socio-political and techno-material dynamics and help bust the pro-Israel myths. As mentioned, hasbara has made several important adaptations relating to precisely these digital media changes in coordination with the army.

During the 2014 war on Gaza, the IDF had 292,000 Twitter followers and was offering dozens of updates a day, including infographs. However, these figures cannot be taken at face value. Its presence was indeed far superior to that offered by Palestinian military groups, such as al-Qassam (the military wing of Hamas), whose account on Twitter had merely 11,900 followers in the same period.$^{88}$ Online media is shaped by an existing colonization of digital infrastructures that reflect the reality of cyber imperialism. ${ }^{89}$ The fact is that existing dominant platforms block most of al-Qassam's accounts, since the majority of companies are hosted in the United States and abide by state wishes and policy regulations. Thus the internet is not a democratic space: Many platforms are not neutral but follow corporate or state orders that mostly favor Israel. But if we zoom out from the military actors, where there is such an unequal balance of forces, and zoom into activist groups, then the number of people sharing and liking hashtags in support of Palestinians is much higher, with pro-Palestinian tweets than being far more numerous than those produced by hasbara. The \#GazaUnderAttack (Figure 3(b)) tweets during the war illustrate this..$^{90}$ The fact that celebrities (e.g., Dwight Howard, the basketball player, and Rihanna, the singer) posted tweets with the \#FreePalestine hashtag also reflects how broadly this political dispositionality is embraced. ${ }^{91}$

Moreover, the contradiction of hyper-mediations turns hasbara audiences into witnesses of injustice. An example of this dynamic is the online video, What Is It Like to Be Attacked By Rocks? It shows scenes of Palestinian youths throwing stones, and it ends dramatically with the question: 'The media consider rock-throwing a harmless provocation. Do you still agree?' The stark irony is that cars pass by on Israeli-only roads in West Bank settlements. These discursive and visual tools become hasbara's own nemesis by disclosing the illegal presence of Israeli colonial settlers, providing evidence of apartheid. ${ }^{92}$ Similarly, in the What it's like to be hit by rockets video, the casualty is a cat that falls from a tree. Again, compared to footage of air bombardments of densely populated apartment blocks in Gaza, this only confirms the military inequality. These contradictions do not just occur as such, they are identified by critics and offered to the media as part of larger awareness campaigns. The tireless attempts of Palestinian activists and their international supporters therefore answers why hasbara has refocused much of its attention toward the activist spaces and networks. This is exactly why the media are not the only space of contention for hasbara.

This perspective offers a better explanation of why, despite Israel's status as an unscrupulous rival with an undeniably stunning media apparatus and a very well-funded public diplomacy, hasbara is not very successful in winning hearts and minds. This perspective

\footnotetext{
${ }^{88}$ In D. Kerr, How Israel and Hamas Weaponized Social Media. Al-Qassem is considered 'a member of a designated foreign terrorist organization', hence banned from YouTube. Whatever the reasoning is, the result is that state violence is preferred over non-state violence.

${ }^{89}$ M. Aouragh (2012) Social Media, Mediation and the Arab Revolutions, Triple-C: Communication, Capitalism \& Critique, 10(2), pp. 518-536.

${ }^{90}$ Cf. B. Dabour (2014) In Asymmetric Twitter War over Gaza, Palestinians are Winning, Electronic Intifada, August 21,2014. Availableathttp://electronicintifada.net/blogs/belal-dabour/asymmetric-twitter-war-over-gaza-palestinians-are-winning, accessed August 15, 2015.

${ }^{91}$ Cf. A. Kaczynski (2014) Rihanna tweets '\#FreePalestine,' quickly deletes tweet, BuzzFeed, July 15, 2014. Available at http://www.buzzfeed.com/andrewkaczynski/rihanna-tweets-freepalestine-quickly-deletes-tweet\#. glwvGrbP, accessed August 15, 2015.

${ }^{92}$ See the video at https://www.youtube.com/watch?v=YZC7A-Lr4Eo, accessed August 15, 2015.
} 
becomes clear once we step outside the disciplinary confines of media studies and regard mediation as a convergence of socio-political and techno-material factors. For example, as a consequence of Israeli military violence (in 2000, 2002, 2004, 2006, 2008-09, 2010, $2012,2014)$, protests began to accumulate and gather speed. This is reflected in a number of surveys conducted between 2002 and 2012. The 2014 attack on Gaza furthered this increasingly critical international public opinion. In the UK the YouGov and The Sunday Times' polls showed that 62 percent of the public believed that the Israeli government was committing war crimes, and 51 percent of those polled by The Sunday Times stated that Israel's actions were unjustified. This increase in sympathy for the Palestinians is particularly interesting in traditionally pro-Israeli media outlets, such as The Sunday Times. ${ }^{93}$ A growing number of people place Israel, together with Iran, Pakistan and North Korea, as the most negatively rated countries. Specifically in EU countries, views on Israeli influence have hardened in Spain (74 percent negative rating, up 8 points) and in France (65 percent, up 9 points). Negative ratings in Germany (69 percent) and Britain (68 percent) remain high. In other English-speaking countries, negative views about Israeli policies also have risen: In Australia (65 percent negative rating, up 7 points) and in Canada (59 percent, up 7 points). ${ }^{94}$ The decline of support among the Jewish community in the UK is particularly telling. British Jews have become increasingly uncomfortable with the right-wing politics of Israel and the ethno-racial expectation that they will close ranks for its sake. ${ }^{95}$

Political engagement on university campuses is among the most interesting challenge that is causing shifts in the public's opinion vis-à-vis Israel. This engagement, in turn, also explains the growth of campus activities by hasbara campaigns. Progressive student bodies endorsing divestment campaigns, such as Boycott, Divestment and Sanctions (BDS), increasingly weaken pro-Israel lobbies and antagonize hasbara initiatives. Consequently, Israel has experienced a growing number of celebrities cancelling cultural events in Israel, at a level that is similar to the boycott and divestment campaigns during the apartheid era in South Africa. It is likely that the growth in boycott campaigns and the increase in street protests have pushed previously controversial topics regarding Palestine further into the public arena. Similarly, it is unsurprising that the Israeli government and its hasbara strategy have identified BDS as a key strategic threat. The double entendre, 'Don't believe the BS in BDS!', used by Prime Minister Benjamin Netanyahu in his speech at the 2014 American Israel Public Affairs Committee (AIPAC) meeting, is telling. ${ }^{96}$ However, this top-level response to a largely grassroots campaign further demonstrates that ordinary people can contradict hasbara messages that emanate via the same dominant media on which public diplomacy relies, and in due course can construct an independent discourse. This dynamic clarifies why hasbara must be refined and yet how, in doing so, it repeatedly fails, or rather why the contradictions that exist between the Israeli message and its reality are becoming ever wider. The additional angle of politically active engagement makes clear that a particular consciousness can be nurtured beyond the reach of public relations or diplomacy.

\footnotetext{
93 For both questionnaires see: http://cdn.yougov.com/cumulus_uploads/document/ejq2q2g7ym/Internal_ Results_140728_War_Crimes_W.pdf; http://cdn.yougov.com/cumulus_uploads/document/ytggo8ho42/YG-Arc hive-Pol-Sunday-Times-results-140725.pdf, accessed August 15, 2015.

${ }^{94}$ See this extensive assessment by the BBC: http://www.worldpublicopinion.org/pipa/pdf/may12/BBCEvals_ May12_rpt.pdf.

${ }^{95}$ Aked et al., The UK's pro-Israel Lobby.

${ }^{96}$ For the full transcript of his speech, see: http://www.haaretz.com/news/diplomacy-defense/1.577920, accessed August 15, 2015.
} 


\section{Conclusion: Meticulous Strategy, Magnificent Failure}

This ostentatiously outrageous lie reads not as evasion, but as a deliberate and cruel assertion of power, not only over life and death, but, at least in the Gaza strip, over truth itself. ${ }^{97}$

For Palestinians, hasbara does something definite: it mediates not only the exercise of power over life and death, but over truth itself. Hasbara has become a multi-levelled project: some can be understood as a form of public diplomacy, or seductive branding, while others take the form of aggressive soft power, or psyops. Following a framework that befits liberal nation-states, mainstream public diplomacy literature provides a separation of these two roles: One where the monopoly and exertion of violence is veiled. This is not the case with Israel, which, according to Molad,

is perceived in the international community as militaristic, masculine, religious, stiffnecked, dangerous, chauvinist, and frightening, and is constantly identified in the international media with images of conflict. ${ }^{98}$

This change mostly is associated with Israel's military operations. International public opinion gradually, and perhaps irrevocably, has shifted toward one in which Israel is perceived as a military aggressor. Simply put, it is more difficult to mask images of conflict when one perpetually is involved in wars. The underlying truth of colonialism, obscured by an ideological bias (Zionism), does not allow hasbara to arrive at the most logical explanation that would be in tune with most public relations approaches or media analyses. In answer to Schleifer (cited at the beginning of this article), who asked how it is that a state with nuclear weapons and reputable intelligence services could fail, the answer is contained in the question. The primacy given to military doctrines, Israel's permanent condition, directs us to what causes the hasbara stalemate. Hasbara cannot make a 'post-conflict' shift as long as it is not based on justice for Palestinians, which, of course, would undermine the Zionist project itself. Thus, hasbara is trapped between a rock and a hard place as this article illustrated. The difference between opinions of governments and ordinary publics regarding Israel epitomizes the immense contradictions. That is why public diplomacy needs to be assessed through state and non-state dynamics, increase of support for Palestine and critique of Israel coincide.

In response to growing international criticism hasbara has undertaken a number of makeovers-refined its earlier style to a slick 'cast doubt' strategy. In the 'Hamas Rockets' red flag model a handmade grenade damaging a tree in Israel, and an Israeli F16 killing 25 people in a massive blast are measured against the same philosophical or ethical standards. Such a conceptual levelling of politics and experiences in a greatly uneven reality reverses oppression and resistance, or cause and effect. This article explored the role of the internet for public diplomacy with reference to techno-military forces and has illustrated how this process intersects with, and is influenced by, a changing media ecology and journalism more generally.

The asymmetry in the military field and the strength and resources of Israeli social media — construed by existing double standards, e.g., online platforms are blocking Hamas

\footnotetext{
${ }^{97}$ Miéville, The Lies that Aren't Meant to Deceive Us.

${ }^{98}$ Molad (2012) Israeli Hasbara: Myths and Facts, p. 11.
} 
pages while accommodating those of the IDF-clearly outweigh those of the Palestinians. However, the overall impact of the Palestinians on social media outweighs that of Israel, defying the mathematical logic that one might presume applies. That an opponent with more resources, superior access to intelligence and crucial international backing is not able fully to impose its will is an important confirmation of activist efforts and solidarity. To understand these contradictory dynamics better, we must take the conceptual dispute outside of the media realm and reconverge it with offline strategies, with grassroots activism. And amid the deeply unequal balance of forces, the struggle for justice only can be a long-term one. It is important to remember that the grassroots struggle against Apartheid South Africa took many decades; without all those initial cracks in the projection of white supremacy by all the big and small solidarity groups across the world, it would not have managed to emanate as a collective that managed to pressure international governments to end their diplomatic and economic support for South Africa.

The lacuna between Israel's desired public persona and overall international perception continues to deepen and pro-Palestinian movements are gaining public support. If anything, the examples discussed in this article have shown that occasions of war create cracks in the dominant media narrative. It is when a parallel common sense seeps through, one that defies many of hasbara's attempts to 'explain' it all away. This 'common sense' is captured by the words chanted in the streets of many capitals across the world in July and August 2014: 'In our thousands - in our millions-we are all Palestinians.' This striking chant proclaims that (pro-) Palestinian public diplomacy, not relying on government interventions, is an international and above all people's objective. The basic fact, therefore, is that every time Israeli propaganda becomes more masterful in its techniques and receives more budgets, it ends in disappointment. Paradoxically, grassroots diplomacy — a public relations that is formed by universal principles of justice and equality—offers qualities that money cannot buy, hence a more aggressive hasbara tends to mobilize more solidarity for Palestinians in the process.

\section{Acknowledgements}

I wish to thank Jamie Allison, Linah Alsafinah, Sai Englert, Ashley Inglis and Mandy Turner for their advice and encouragement, as well as the anonymous reviewers for their feedback.

\section{References}

Alexander, A. \& Aouragh, M. (2011) The Egyptian Experience: Sense and Nonsense of the Internet Revolution, International Journal of Communication, 5, pp. 1344-1358.

Alexander, A. \& Aouragh, M. (2014) Egypt's Unfinished Revolution: The Role of the Media Revisited, International Journal of Communication, 8, pp. 890-915.

Allan, D. \& Brown, C. (2010) The Mavi Marmara At the Frontlines Of Web 2.0, Journal of Palestine Studies, 40(1), pp. 63-77.

Alsaafin, L. (2013) Palestinians Turn to Facebook in Fight Against Occupation, Al Monitor. Available at: http://www. al-monitor.com/pulse/originals/2013/04/social-media-palestinian-activism.html\#, accessed August 15, 2015.

Aked, H., Mills, T., Griffin, T. \& Miller, D. (2013) The UK's pro-Israel Lobby in Context, Open Democracy, December 2, 2013. Available at: https://www.opendemocracy.net/ourkingdom/tom-mills-hilary-aked-tomgriffin-david-miller/uk's-pro-israel-lobby-in-context, accessed August 15, 2015.

Aouragh, M. (2008) Virtual Intifada: Online Activism and Everyday Resistance, Journal of Arab and Muslim Media Research, 1(2), pp. 109-130.

Aouragh, M. (2011) Palestine Online: Transnationalism, the Internet and the Reconstruction of Identity. (London: I. B. Tauris). 
Aouragh, M. (2012) Social Media, Mediation and the Arab Revolutions, Triple-C: Communication, Capitalism \& Critique, 10(2), pp. 518-536.

Aouragh, M. (2015) Between Cybercide and Cyber Intifada: Technologic (dis-) Empowerment of Palestinian Activism. In: Jayyusi, L., \& Roald, A. S. (eds) Media and Political Contestation in the Contemporary Arab World: A Decade of Change, pp. 129-160 (New York: Palgrave Macmillan).

Artz, L. (2006) On the Material and the Dialectic: Toward a Class Analysis of Communication. In: Artz, L., Macek, S., \& Cloud, D. L. (eds) Marxism and Communication Studies: The Point is to Change it, pp. 5-51 (New York: Peter Land).

Artz, L., Macek, S. \& Cloud, D. L. (eds) (2006) Marxism and Communication Studies: The Point is to Change it. (New York: Peter Land).

Baram, D. (2004) Disenchantment: The Guardian and Israel. (London: Guardian Books).

Bishara, A. (2013) Back Stories: U.S. News Production and Palestinian Politics. (Palo Alto: Stanford University Press).

Blumenthal, M. (2013) Israel Cranks up the PR Machine. The Nation, November 4, 2013.

Borgstede, M. (2013) Tweet Offensive: Social Media is Israeli Military's Newest Weapon, July 21, 2013. Available at: http://www.worldcrunch.com/culture-society/tweetoffensive-social-media-is-israeli-military-039-s-newestweapon/israel-tsahal-social-media-idf-avital-leibovich-hamas-hezbollah/c3s12783/\#.U-jwgBZeNG5, accessed August 15, 2015.

Chomsky, N. \& Herman, E. S. (1988) Manufacturing Consent. The Political Economy of the Mass Media. (New York: Pantheon Books).

Cloud, D. L. (2006) Change Happens: Materialist Dialectics and Communication Studies, in: Artz, L., Macek, S. \& Cloud, D. L. (eds) Marxism and Communication Studies: The Point is to Change it, pp. 53-70 (Peter Land: New York).

Eisenberg, L. Z. (2013) Review of Shalom, Zaki. 2012. The Role of U.S. Diplomacy in the Lead-Up to the Six-Day War: Balancing Moral Commitments and National Interests, Digest of Middle East Studies, 22(1), pp. 190-193.

Gilboa, E. (2006) Public Diplomacy: The Missing Component in Israel's Foreign Policy, Israel Affairs, 12(4), pp. 715-747.

Hall, I. (2010) The Transformation of Diplomacy: Mysteries, Insurgencies and Public Relations, International Affairs, 86(1), pp. 247-256.

Hage, G. (2003) 'Comes a Time We Are All Enthusiasm': Understanding Palestinian Suicide Bombers in Times of Exighophobia, Public Culture, 15(1), pp. 65-89.

Harb, Z. (2011) Channels of Resistance in Lebanon (London: I. B. Tauris).

Hassman, R. (2008) The Israel Brand: Nation Marketing under Constant Conflict. Available at: http://spirit.tau. ac.il/government/downloads/Rommy_Hassman_HebBLINT.pdf, accessed August 15, 2015.

INCITE! (2007) The Revolution Will Not Be Funded (New York: South End Press).

Jansen, S. (2013) Review - New Public Diplomacy in the 21st Century, in: E-International Relations, August 26, 2013. Available at: http://www.e-ir.info/2013/08/26/review-new-public-diplomacy-in-the-21st-century/, accessed August 15, 2015.

Kuntsman, A \& Stein, R. (2010) Another War Zone: New Media and the Israeli-Palestinian Conflict, Middle East Report Online, September. Available at: http://www.merip.org/mero/interventions/another-war-zone, accessed August 15, 2015.

Kerr, D. (2014) How Israel and Hamas Weaponized Social Media, CNET, January 13, 2014. Available at: http:// www.cnet.com/uk/news/how-israel-and-hamas-weaponized-social-media, accessed August 15, 2015.

Liphshiz, C. (2014) From Dutch Situation Room, pro-Israel Volunteers Defend Jewish State on Social Media, Jewish Telegraphic Agency, July 29, 2014. Available at: http://www.jta.org/2014/07/29/news-opinion/world/ in-dutch-situation-room-pro-israel-volunteers-defend-jewish-state-on-social-media, accessed August 15, 2015.

Mackey, R. (2014) Young Israelis Fight Hashtag Battle to Defend \#IsraelUnderFire, The New York Times, July 15, 2014. Available at: http://www.nytimes.com/2014/07/16/world/middleeast/young-israelis-fight-hashtagbattle-to-defend-israelunderfire.html?_r=1, accessed August 15, 2015.

Makuch, B. (2014) Israel Is Outgunning Hamas on Social Media, Too. Motherboard Vice, July 25, 2014. Available at: http://motherboard.vice.com/read/israel-is-outgunning-hamas-on-social-media-too, accessed August 15, 2015.

Miéville, C. (2006) The Lies that Aren't Meant to Deceive Us, Socialist Review (November) Issue 311. Available at: http://socialistreview.org.uk/311/lies-arent-meant-deceive-us, accessed August 15, 2015.

Molad. (2012) 'Israeli Hasbara: Myths and Facts.' Molad: Center for the Renewal of Israeli Democracy. Available at: http://www.molad.org/images/upload/researches/79983052033642.pdf, accessed August 15, 2015.

Mor, B. (2006) Public Diplomacy in Grand Strategy, Foreign Policy Analysis, 2, pp. 157-176. 
Najjar, A. (2010) Othering the Self: Palestinians Narrating the War on Gaza in the Social Media, Journal of Middle East Media, 6(1), pp. 1-30.

Nye, J. (2005) The Means to Success in World Politics (New York: Public Affairs).

Panment, J. (2013) New Public Diplomacy in the 21st Century (London: Routledge).

Papacharissi, Z \& Oliveira M. (2011) The Rhythms of News Storytelling on Twitter: Coverage of the January 25th Egyptian Uprising on Twitter. Paper presented at the World Association for Public Opinion Research Conference, Amsterdam, September 2011. Available at: http://www.researchgate.net/publication/264645964_ Affective_News_and_Networked_Publics_The_Rhythms_of_News_Storytelling_on_Egypt, accessed August 2015.

Philo, G. \& Berry, M. (2011) More Bad News from Israel (London: Pluto Press).

Senor, D. \& Singer, S. (2009) Start-Up Nation: The Story of Israel's Economic Miracle (New York: McClelland $\&$ Stewart).

Saeed, S. (2010) News Media, Public Diplomacy and the War on Terror, in: M. Zweiri and Emma C. Murphy (eds) The New Arab Media: Technology, Image and Perception (Reading, UK: Ithaca Press).

Said, E. W. (1995) Peace and Its Discontents: Essays on Palestine in the Middle East Peace Process (New York: Vintage Books).

Said, E. W. (2001) Propaganda and War, in: Media Monitors Networks, 31, August. Available at: http://www. mediamonitors.net/edward37.html, accessed August 15, 2015.

Schleifer, R. (2003) Jewish and Contemporary Histories of Israeli Hasbara, Jewish Political Studies Review, 15(1-2), pp. 123-153.

Schleifer, R. (2011) Perspectives of Psychological Operations (PSYOP) in Contemporary Conflicts: Essays in Winning Hearts and Minds (Brighton and Portland: Sussex Academic Press).

Shalom, Z. (2012) The Role of U.S. Diplomacy in the Lead-Up to the Six-Day War: Balancing Moral Commitments and National Interests (Brighton, UK: Sussex Academic Press).

Sheafer, T. \& Shenhav, S. R. (2010) Mediated Public Diplomacy in a New Era of Warfare, The Communication Review, 12, pp. 272-283.

Sherman, M. (2013) Into the Fray: Dereliction of Duty, The Jerusalem Post, October 25, 2013. Available at: http:// www.jpost.com/Opinion/Columnists/Into-The-Fray-Dereliction-of-duty-329723, accessed August 15, 2015.

Sherwood, H. (2014) Israel and Hamas on Social Media. The Guardian, July 16, 2014. Available at: http://www. theguardian.com/world/2014/jul/16/israel-hamas-clash-social-media, accessed August 15, 2015.

Siapera, E. (2013) Tweeting \#Palestine: Twitter and the Mediation of Palestine, International Journal of Cultural Studies, 17(6), pp. 539-555. doi: http://dx.doi.org/10.1177/1367877913503865.

Sienkiewicz, M. (2012) Out of Control: Palestinian News Satire and Government Power in the Age of Social Media, Popular Communication: The International Journal of Media and Culture, 10(1-2), pp. 106-118.

Snow, N. (2008) Rethinking Public Diplomacy, in: Snow, N. \& Taylor, P. (eds) Routledge Handbook of Public Diplomacy, pp. 3-11 (London: Routledge).

Snow, N. \& Taylor, P. (eds) (2008) Routledge Handbook of Public Diplomacy (London: Routledge).

Sofer, S. (1998) Zionism and the Foundations of Israeli Diplomacy (New York: Cambridge University Press).

Sparks, C. (2006) Contradictions of Capitalist Media Practice, in: Artz, L., Macek, S. \& Cloud, D. L. (eds) (2006) Marxism and Communication Studies: The Point is to Change it, pp. 111-132 (New York: Peter Land).

Taylor, P. (2008) Public Diplomacy and Strategic Communications, in: Snow, N. \& Taylor, P. (eds) Routledge Handbook of Public Diplomacy, pp. 12-18 (London: Routledge).

United Nations Office for the Coordination of Humanitarian Affairs (UNOCHA) (2014) Gaza Crisis Appeal: September 2014 Update.

United Nations Office for the Coordination of Humanitarian Affairs (UNOCHA) (n.d.) OpT - ReliefWeb news.

White, B. (2005) Diplomacy, in: Baylis, J., Smith, S. \& Owens, P. (eds) The Globalization of World Politics, 3rd edn, pp. 387-403 (Oxford: Oxford University Press).

White, B. (2013) Abba Eban's Comments on the Idiocy of Hasbara Just as True Three Decades Later, Electronic Intifada, February 18, 2013. Available at: https://electronicintifada.net/blogs/ben-white/abba-ebans-commentsidiocy-hasbara-just-true-three-decades-later, accessed August 15, 2015 